\title{
Agonist-Evoked Increases in Intra-Platelet Zinc Couple to Functional Responses
}

\author{
Niaz S. Ahmed ${ }^{1}$ Maria E. Lopes Pires ${ }^{1}$ Kirk A. Taylor ${ }^{2} \quad$ Nicholas Pugh $^{1}$ \\ ${ }^{1}$ School of Life Sciences, Anglia Ruskin University, Cambridge, \\ United Kingdom \\ ${ }^{2}$ Cardio-Respiratory Interface Section, National Heart and Lung \\ Institute, Imperial College London, London, United Kingdom \\ Address for correspondence Nicholas Pugh, PhD, School of Life \\ Sciences, Anglia Ruskin University, East Road, Cambridge, CB1 1PT, \\ United Kingdom (e-mail: Nicholas.Pugh@anglia.ac.uk).
}

Thromb Haemost 2019;119:128-139.

\begin{abstract}
Background Zinc $\left(\mathrm{Zn}^{2+}\right)$ is an essential trace element that regulates intracellular processes in multiple cell types. While the role of $\mathrm{Zn}^{2+}$ as a platelet agonist is known, its secondary messenger activity in platelets has not been demonstrated.

Objectives This article determines whether cytosolic $\mathrm{Zn}^{2+}$ concentrations $\left(\left[\mathrm{Zn}^{2+}\right]_{\mathrm{i}}\right)$ change in platelets in response to agonist stimulation, in a manner consistent with a secondary messenger, and correlates the effects of $\left[\mathrm{Zn}^{2+}\right]_{i}$ changes on activation markers. Methods Changes in $\left[\mathrm{Zn}^{2+}\right]_{i}$ were quantified in Fluozin-3 (Fz-3)-loaded washed, human platelets using fluorometry. Increases in $\left[\mathrm{Zn}^{2+}\right]_{i}$ were modelled using $\mathrm{Zn}^{2+}$ specific chelators and ionophores. The influence of $\left[\mathrm{Zn}^{2+}\right]_{i}$ on platelet function was assessed using platelet aggregometry, flow cytometry and Western blotting.

Results Increases of intra-platelet Fluozin-3 (Fz-3) fluorescence occurred in response to stimulation by cross-linked collagen-related peptide (CRP-XL) or U46619, consistent with a rise of $\left[\mathrm{Zn}^{2+}\right]_{\text {i. }}$. Fluoresence increases were blocked by $\mathrm{Zn}^{2+}$ chelators and modulators of the platelet redox state, and were distinct from agonist-evoked $\left[\mathrm{Ca}^{2+}\right]_{i}$ signals. Stimulation of platelets with the $\mathrm{Zn}^{2+}$ ionophores clioquinol (Cq) or pyrithione (Py) caused sustained increases of $\left[\mathrm{Zn}^{2+}\right]_{i}$, resulting in myosin light chain phosphorylation, and cytoskeletal re-

Keywords

- platelets

- zinc

- platelet activation

- signal transduction

- secretory vesicles

- granule release arrangements which were sensitive to cytochalasin-D treatment. Cq stimulation resulted in integrin $\alpha_{\| \mathrm{lb}} \beta_{3}$ activation and release of dense, but not $\alpha$, granules. Furthermore, $\mathrm{Zn}^{2+}$ ionophores induced externalization of phosphatidylserine.

Conclusion These data suggest that agonist-evoked fluctuations in intra-platelet $\mathrm{Zn}^{2+}$ couple to functional responses, in a manner that is consistent with a role as a secondary messenger. Increased intra-platelet $\mathrm{Zn}^{2+}$ regulates signalling processes, including shape change, $\alpha_{11 b} \beta_{3}$ up-regulation and dense granule release, in a redox-sensitive manner.
\end{abstract}

\section{Introduction}

Zinc $\left(\mathrm{Zn}^{2+}\right)$ is an essential trace element, serving as a cofactor for 10 to $15 \%$ of proteins encoded within the human genome. ${ }^{1}$ It is acknowledged as an extracellular signalling molecule in glycinergic and GABAergic neurones, and is released into the synaptic cleft following excitation.,3 $\mathrm{Zn}^{2+}$ is concentrated in atherosclerotic plaques and released from damaged epithelial cells, and is released from platelets along with their $\alpha$-granule cargo following collagen stimulation. ${ }^{4}$ Therefore, increased concentrations of unbound or labile (free) $\mathrm{Zn}^{2+}$ are likely to be present at areas of haemostasis, and may be much higher in the microenvironment of a growing thrombus. $\mathrm{Zn}^{2+}$ plays a role in haemostasis by contributing to wound healing, ${ }^{5}$ and regulating coagulation,

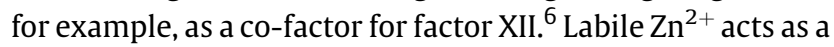

received

June 26, 2018

accepted after revision

October 31, 2018
DOI https://doi.org/

10.1055/s-0038-1676589.

ISSN 0340-6245. @ 2019 Georg Thieme Verlag KG
Stuttgart · New York
License terms

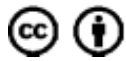


platelet agonist, being able to induce tyrosine phosphorylation, integrin $\alpha_{\mathrm{IIb}} \beta_{3}$ activation and aggregation at high concentrations, while potentiating platelet responses to other agonists at lower concentrations. ${ }^{7} \mathrm{Zn}^{2+}$ is directly linked to platelet function in vivo, as dietary $\mathrm{Zn}^{2+}$ deficiency of humans or rodents manifests with a bleeding phenotype that reverses with $\mathrm{Zn}^{2+}$ supplementation.

Labile, protein-bound and membrane-bound, $\mathrm{Zn}^{2+}$ pools are found within multiple cell types, including immune cells and neurones. These pools are inter-changeable, allowing increases in the bioavailability of $\mathrm{Zn}^{2+}$ to $\mathrm{Zn}^{2+}$-sensitive proteins following signalling-dependent processes. In this manner, $\mathrm{Zn}^{2+}$ is acknowledged to behave as a secondary messenger. ${ }^{8}$ In nucleated cells, $\mathrm{Zn}^{2+}$ is released from intracellular granules into the cytosol via $\mathrm{Zn}^{2+}$ transporters, or from $\mathrm{Zn}^{2+}$-binding proteins such as metallothioneins, following engagement of extracellular receptors. For example, a role for $\mathrm{Zn}^{2+}$ as a secondary messenger has been shown in mast cells, where engagement of the $F_{C} \varepsilon$ receptor I results in rapid increases in intracellular $\left.\mathrm{Zn}^{2+}\left(\mathrm{Zn}^{2+}\right]_{\mathrm{i}}\right)$. This 'zinc wave' modulates transcription of cytokines, and affects tyrosine phosphatase activity. ${ }^{8} \mathrm{Zn}^{2+}$ also acts as a secondary messenger in monocytes, where stimulation with lipopolysaccharide results in increases in $\left[\mathrm{Zn}^{2+}\right]_{\mathrm{i}}$, suggestive of a role in transmembrane signalling. ${ }^{9}$ Agonist-evoked changes of $\left[\mathrm{Zn}^{2+}\right]_{\mathrm{i}}$ modulate signalling proteins (i.e. protein kinase C [PKC], calmodulin-dependent protein kinase II [CamKII] and interleukin receptorassociated kinase) in a similar manner to calcium $\left(\mathrm{Ca}^{2+}\right)$ dependent processes. ${ }^{4,8,10}$ While the role of $\mathrm{Zn}^{2+}$ as a secondary messenger in nucleated cells has gathered support in recent years, agonist-dependent regulation of $\left[\mathrm{Zn}^{2+}\right]_{i}$ in platelets during thrombosis has yet to be demonstrated.

Here, we utilize $\mathrm{Zn}^{2+}$-specific fluorophores, chelators and ionophores to investigate the role of $\left[\mathrm{Zn}^{2+}\right]_{i}$ fluctuations in platelet behaviour. We show that agonist-evoked elevation of $\left[\mathrm{Zn}^{2+}\right]_{\mathrm{i}}$ regulates platelet shape change, dense granule release and phosphatidylserine (PS) exposure. These findings indicate a role for $\mathrm{Zn}^{2+}$ as a secondary messenger, which may have implications for the understanding of platelet signalling pathways involved in thrombosis during adverse cardiovascular events.

\section{Experimental Procedures}

Materials: Fluozin-3-Am (Fz-3, $\mathrm{Zn}^{2+}$ indicator) and Fluo-4-AM $\left(\mathrm{Ca}^{2+}\right.$ indicator) were from Invitrogen (Paisley, United Kingdom). Z-VAD (pan-caspase inhibitor) was from R\&D Systems (Abingdon, United Kingdom). Primary antivasodilator-stimulated phosphoprotein (VASP) (Ser157) and anti-myosin light chain (MLC) (Ser19) antibodies were from Cambridge Bioscience (Cambridge, United Kingdom), and fluorescently conjugated procaspase-activating compound 1 (PAC-1), CD62P and CD63 antibodies were from BD Biosciences (Oxford, United Kingdom). Cross-linked collagenrelated peptide (CRP-XL; glycoprotein VI [GpVI] agonist) was from Professor Richard Farndale (Cambridge, United Kingdom), U46619 (thromboxane [TP] $\alpha$ receptor agonist) was from Tocris (Bristol, United Kingdom), thrombin (protease-activated receptor [PAR] agonist) was from Sigma Aldrich (Poole, United Kingdom) and cytochalasin-D (Cyt-D, actin polymerization inhibitor) was from AbCam (Cambridge, United Kingdom). Clioquinol (Cq, $\mathrm{Zn}^{2+}$ ionophore, $\mathrm{C}_{9} \mathrm{H}_{5} \mathrm{ClINO}, \mathrm{K}_{\mathrm{d}} \mathrm{Zn}: 10^{-7} \mathrm{M}, \mathrm{K}_{\mathrm{d}} \mathrm{Ca}: 10^{-4.9} \mathrm{M}$ ), pyrithione (Py, $\mathrm{Zn}^{2+}$ ionophore, $\left.\mathrm{C}_{10} \mathrm{H}_{8} \mathrm{~N}_{2} \mathrm{O}_{2} \mathrm{~S}_{2}, \mathrm{~K}_{\mathrm{d}} \mathrm{Zn}: 10^{-7} \mathrm{M}, \mathrm{K}_{\mathrm{d}} \mathrm{Ca}: 10^{-4.9} \mathrm{M}\right)$, A23187 ( $\mathrm{Ca}^{2+}$ ionophore, $\left.\mathrm{C}_{29} \mathrm{H}_{37} \mathrm{~N}_{3} \mathrm{O}_{6}\right)$, N,N,N',N'-Tetrakis(2pyridylmethyl)ethylenediamine (TPEN, $\mathrm{Zn}^{2+}$ chelator, $\mathrm{K}_{\mathrm{d}} \mathrm{Zn}$ : $\left.2.6 \times 10^{-16} \mathrm{M}, \mathrm{K}_{\mathrm{d}} \mathrm{Ca}: 4.4 \times 10^{-5} \mathrm{M}^{11-14}\right)$, dimethyl-bis(aminophenoxy)ethane-tetraacetic acid (DM-BAPTA)-AM $\left(\mathrm{C}_{34} \mathrm{H}_{40} \mathrm{~N}_{2} \mathrm{O}_{18}, \quad \mathrm{~K}_{\mathrm{d}} \mathrm{Zn}: 7.9 \times 10^{-9} \mathrm{M}, \quad \mathrm{K}_{\mathrm{d}} \mathrm{Ca}: 110 \times 10^{-9}\right.$ $\mathrm{M}^{11-14}$ ) and membrane permeant anti-oxidizing proteins, polyethylene glycol-superoxide dismutase (PEG-SOD) and PEG-catalase (CAT) were from Sigma Aldrich. Unless stated, all other reagents were from Sigma Aldrich.

Preparation of washed human platelets: This study was approved by the Research Ethics Committee at Anglia Ruskin University and informed consent was obtained in accordance with the Declaration of Helsinki. Blood was donated by healthy human volunteers, free from medication for 2 weeks. Blood was collected into $11 \mathrm{mM}$ sodium citrate and washed platelets were prepared as described previously. ${ }^{7}$ Unless otherwise stated, to isolate the mechanisms of $\mathrm{Zn}^{2+}$ fluctuations from other cation-specific effects, experiments were performed in the absence of extracellular $\mathrm{Ca}^{2+}$.

Cation mobilisation studies: For studies of $\left[\mathrm{Zn}^{2+}\right]_{i}$ or $\left[\mathrm{Ca}^{2+}\right]_{\mathrm{i}}$ mobilization, platelet-rich plasma was loaded with Fz-3 $\left(2 \mu \mathrm{M}, 30\right.$ minutes, $\left.37^{\circ} \mathrm{C}\right)$, or Fluo-4 $(2 \mu \mathrm{M}, 30$ minutes, $\left.37^{\circ} \mathrm{C}\right)$. $\mathrm{Fz}-3$ is responsive to $\mathrm{Zn}^{2+}$ in the $\mathrm{nM}$ range and is not significantly affected by $\mathrm{Ca}^{2+15}$ Platelets were collected by centrifugation (350 $\times \mathrm{g}, 15$ minutes), re-suspended in $\mathrm{Ca}^{2+}$ free Tyrode's buffer (in mM: $140 \mathrm{NaCl}, 5 \mathrm{KCl}, 10 \mathrm{HEPES}, 5$ glucose, $0.42 \mathrm{NaH}_{2} \mathrm{PO}_{4}, 12 \mathrm{NaHCO}_{3}, \mathrm{pH} 7.4$ ) and rested at $37^{\circ}$ $\mathrm{C}$ for 30 minutes prior to use. Fluorescence was monitored using a Fluoroskan Ascent fluorometer (ThermoScientific, United Kingdom) using $488 \mathrm{~nm}$ and $538 \mathrm{~nm}$ excitation and emission filters, respectively. Washed Fz-3 or Fluo-4 loaded platelet suspensions were treated with ionophores or chelators to calibrate $R_{\max }$ or $R_{\min }$ values (-Supplementary Fig. S1, available in the online version). Results are expressed as an increase of background-corrected fluorescence at each time point relative to baseline: ( $\left.\left.F-F_{\text {background }}\right) / F_{0}-F_{\text {background }}\right)$.

Optical aggregometry: Aggregometry was performed with washed platelet suspensions under stirring conditions at $37^{\circ} \mathrm{C}$ in an AggRam light transmission aggregometer (Helena Biosciences, Gateshead, United Kingdom). ${ }^{7}$ Aggregation traces were acquired using a proprietary software (Helena Biosciences) and analysed within GraphPad Prism (Version 6.03).

Confocal microscopy: Images of platelets adhering to coated fibrinogen coverslips $(100 \mu \mathrm{M})$ were acquired using a LSM510/Axiovert laser scanning confocal microscope with $60 \times$ oil NA1.45 objective (Zeiss, United Kingdom). Surface coverage of $\mathrm{DIOC}_{6}$-stained platelets was quantified using ImageJ (v1.45, National Institutes of Health, Bethesda, Maryland, United States).

Western blotting: Western blotting was performed as described previously. ${ }^{7}$ Briefly, polyvinylidene difluoride membranes were incubated with MLC (1:400) or VASP 
(Ser157, 1:400) primary antibodies, and horseradish peroxidase-conjugated secondary antibodies $(1: 7,500)$.

Flow cytometry: Washed platelet suspensions were incubated with fluorescently conjugated antibodies targeting markers of platelet activation: PAC-1 ( $\alpha_{\mathrm{II}} \beta_{3}$ activation), CD62P ( $\alpha$ granule release) and CD63 (dense granule release). Antibody binding following agonist or ionophore stimulation was assessed using an Accuri C6 flow cytometer (BD Biosciences).

Data analysis: Maximum and minimum aggregation and $F / F_{0}$ values were calculated using Microsoft Excel. Western blots were analysed using ImageJ. Data were analysed in GraphPad Prism by two-way analysis of variance followed by Tukey's post hoc test. Significance is denoted as ${ }^{* * *} p<0.001$, ${ }^{* *} p<0.01$ or ${ }^{*} p<0.05$.

\section{Results}

$\left[\mathrm{Zn}^{2+}\right]_{\mathrm{i}}$ fluctuations coordinate receptor stimulation with signalling responses in nucleated cells. ${ }^{8}$ To investigate whether intra-platelet $\mathrm{Zn}^{2+}$ fluctuates during activation, agonistevoked changes of $\left[\mathrm{Zn}^{2+}\right]_{i}$ were monitored in washed platelet suspensions, loaded with the $\mathrm{Zn}^{2+}$-specific fluorophore, $\mathrm{Fz}-3$. Stimulation with conventional platelet agonists CRP-XL and U46619 induced rapid, dose-dependent increases of fluorescence peaking after approximately 2 minutes, consistent with increases in $\left[\mathrm{Zn}^{2+}\right]_{\mathrm{i}}$. At 6 minutes, $1 \mu \mathrm{g} / \mathrm{mL}$ CRP-XL or $10 \mu \mathrm{M}$ U46619 stimulation increased $F / F_{0}$ to $2.0 \pm 0.1$ and $1.2 \pm 0.1$ $\mathrm{AU}$, respectively (compared with $0.9 \pm 0.2 \mathrm{AU}$ for the vehicle control, $p<0.05$, - Fig. 1A, B). Conversely, thrombin stimulation did not elevate Fz-3 fluorescence ( - Fig. 1C). These data indicate that platelet activation via GpVI and TP, but not via PARs, leads to signalling responses that result in the elevation

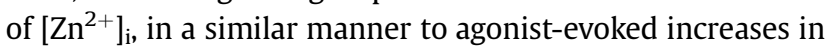
$\left[\mathrm{Ca}^{2+}\right]_{\mathrm{i}}$. Inclusion of $2 \mathrm{mM} \mathrm{CaCl}_{2}$ in the extracellular medium did not significantly affect agonist-evoked responses (-Supplementary Fig. S2, available in the online version).

Experiments were performed to confirm the specificity of fluorescence fluctuations for $\mathrm{Zn}^{2+}$. Platelets were pre-treated with the intracellular $\mathrm{Zn}^{2+}$-specific chelator TPEN $(50 \mu \mathrm{M})$ prior to stimulation with $1 \mu \mathrm{g} / \mathrm{mL}$ CRP-XL. Fz-3 responses were reduced to $1.1 \pm 0.1 \mathrm{AU}$, compared with of $2.0 \pm 0.1$
AU for CRP-XL stimulation alone ( $p<0.05,-$ Fig. 2A). Interestingly, treatment with DM-BAPTA $(10 \mu \mathrm{M})$, a non-specific cation chelator, led to a similar reduction (to $1.0 \pm 0.1 \mathrm{AU}$, $p<0.05$ ). Abrogation of Fz-3 fluorescence was also observed following stimulation with U46619 $(10 \mu \mathrm{g} / \mathrm{mL})$, where TPEN or DM-BAPTA treatment reduced $F / F_{0}$ plateau levels from $1.2 \pm 0.1$ to $0.8 \pm 0.1 \mathrm{AU}$ and $1.0 \pm 0.1 \mathrm{AU}$, respectively $(p<0.05$, - Fig. 2B). Further experiments were performed to investigate the influence of cation chelation on $\left[\mathrm{Ca}^{2+}\right]_{\mathrm{i}}$ fluctuations using Fluo-4-loaded platelets. As previously demonstrated, CRP-XL- and U46619-induced $\mathrm{Ca}^{2+}$ signals were absent following BAPTA treatment $\left(F / F_{0}\right.$ signals were reduced from $1.6 \pm 0.2$ to $0.8 \pm 0.1 \mathrm{AU}$, and from $1.4 \pm 0.1$ to $0.9+0.0 \mathrm{AU}$, for CRP-XL and U46619 stimulation, respectively, $p<0.05$, - Fig. 2D, E). However, Fluo-4 fluorescence was not significantly affected by TPEN treatment $(1.5 \pm 0.2$ and $1.2 \pm 0.1 \mathrm{AU}$ for CRP-XL and U46619, respectively, ns) indicating that TPEN does not chelate $\left[\mathrm{Ca}^{2+}\right]_{\mathrm{i}}$, and that $\mathrm{Fz}-3$ signals are attributable to $\left[\mathrm{Zn}^{2+}\right]_{\mathrm{i}}$ with no influence from other cations. Furthermore, these data demonstrate that fluctuations in $\left[\mathrm{Zn}^{2+}\right]_{\mathrm{i}}$ do not affect agonist-evoked $\mathrm{Ca}^{2+}$ signals.

Agonist-evoked $\left[\mathrm{Zn}^{2+}\right]_{\mathrm{i}}$ increases may result from release of membrane-bound intracellular stores or by liberation from metal-binding proteins (e.g. metallothioneins) in response to redox-mediated modifications to thiol groups. ${ }^{16}$ To investigate the nature of the $\mathrm{Zn}^{2+}$ source, platelets were treated with membrane-permeant anti-oxidizing proteins PEG-SOD and PEG-CAT, ${ }^{17}$ and CRP-XL-evoked $\left[\mathrm{Zn}^{2+}\right]_{\mathrm{i}}$ fluctuations were monitored. PEG-SOD and PEG-CAT both abolished CRP-XLinduced increases of $\mathrm{Fz}-3$ fluorescence, indicating redoxdependent modulation of $\mathrm{Zn}^{2+}$ release (PEG-SOD and PEGCAT reduced $F / F_{0}$ plateaus following $1 \mu \mathrm{g} / \mathrm{mL}$ CRP-XL treatment from $2.0 \pm 0.1$ to $1.2 \pm 0.1 \mathrm{AU}$ and $1.3 \pm 0.1 \mathrm{AU}$, respectively, $p<0.05$, -Fig. 2A). This is consistent with published data showing a greater capacity for GpVI to influence redox signalling than other receptors. ${ }^{18}$ Similarly, PEG-SOD and PEGCAT abolished U46619-induced $\left[\mathrm{Zn}^{2+}\right]_{\mathrm{i}}$ responses (to $1.0 \pm 0.0$ and $1.1 \pm 0.0 \mathrm{AU}$, respectively, following $10 \mu \mathrm{M} \mathrm{U} 46619$ stimulation, $p<0.05$, - Fig. 2B). PEG-SOD and PEG-CAT did not affect CRP-XL- or U46619-mediated Fluo-4 fluorescence, suggesting that $\left[\mathrm{Zn}^{2+}\right]_{\mathrm{i}}$ but not $\left[\mathrm{Ca}^{2+}\right]_{\mathrm{i}}$ signals are regulated by redox-sensitive processes.
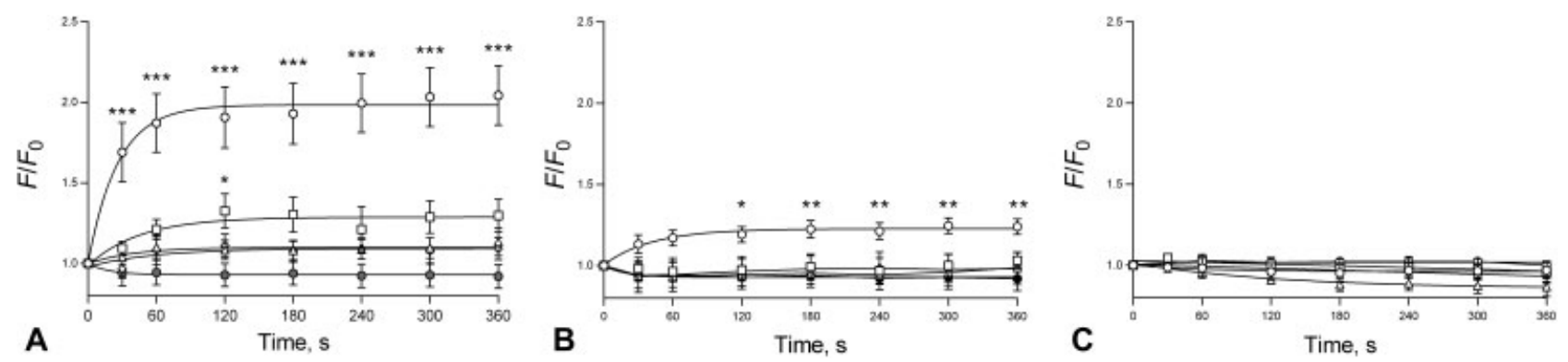

Fig. 1 Agonist-dependent platelet activation via GpVI or TP, but not PARs elevates $\left[\mathrm{Zn}^{2+}\right]_{\text {i }}$. Fz-3-labelled washed human platelets were stimulated by CRP-XL (A), U46619 (B) or thrombin (C) and $\left[\mathrm{Zn}^{2+}\right]_{i}$ fluctuations were monitored over 6 minutes using fluorometry. (A) Fz-3 responses to $\bigcirc 1 \mu \mathrm{g} / \mathrm{mL}, \square 0.3 \mu \mathrm{g} / \mathrm{mL}, \triangle 0.1 \mu \mathrm{g} / \mathrm{mL}, \diamond 0.03 \mu \mathrm{g} / \mathrm{mL}$ CRP-XL or $\bullet$ vehicle (DMSO). (B) Fz-3 responses to $\bigcirc 10 \mu \mathrm{M}, \square 3 \mu \mathrm{M}, \triangle$ $1 \mu \mathrm{M}, \diamond 0.3 \mu \mathrm{MU} 46619$ or $\bullet$ vehicle (DMSO). (C) Fz-3 responses to, $\bigcirc 1 \mathrm{U} / \mathrm{mL}, \square 0.3 \mathrm{U} / \mathrm{mL}, \triangle 0.1 \mathrm{U} / \mathrm{mL}, \diamond 0.03 \mathrm{U} / \mathrm{mL}$ thrombin or $\bullet$ vehicle (DMSO). Data are mean \pm standard error of the mean (SEM) from at least 8 independent experiments. Significance is denoted as ${ }^{* * *} p<0.001$, ${ }^{* *} p<0.01$ or $^{*} p<0.05$. 
CRP-XL

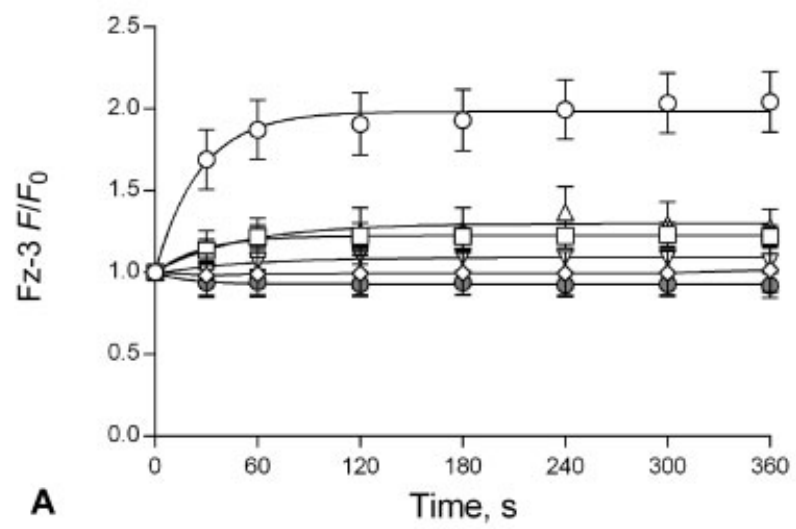

U46619

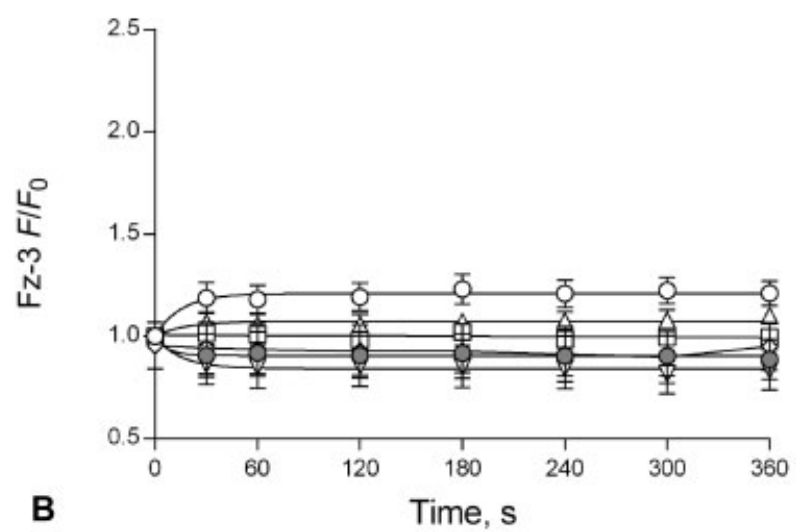

$\mathrm{H}_{2} \mathrm{O}_{2}$

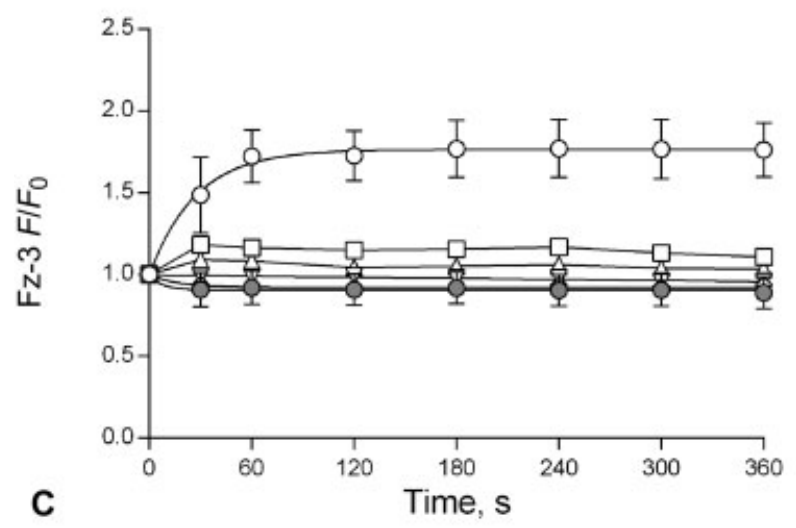

CRP-XL

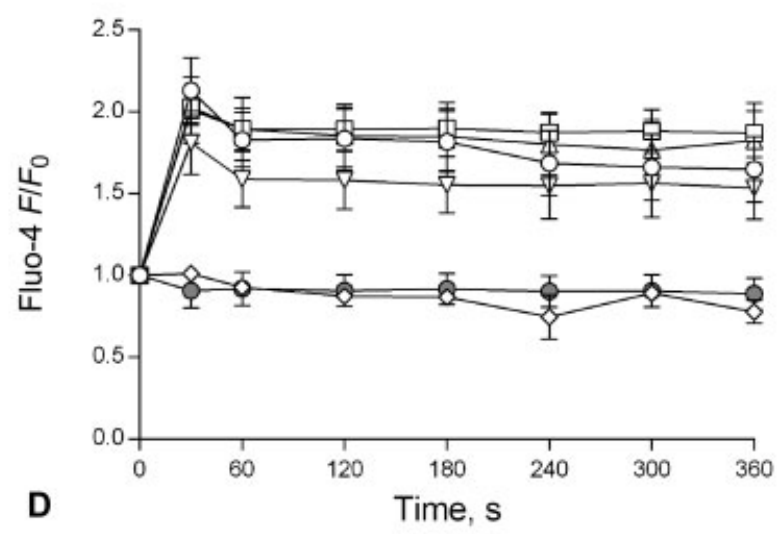

U46619

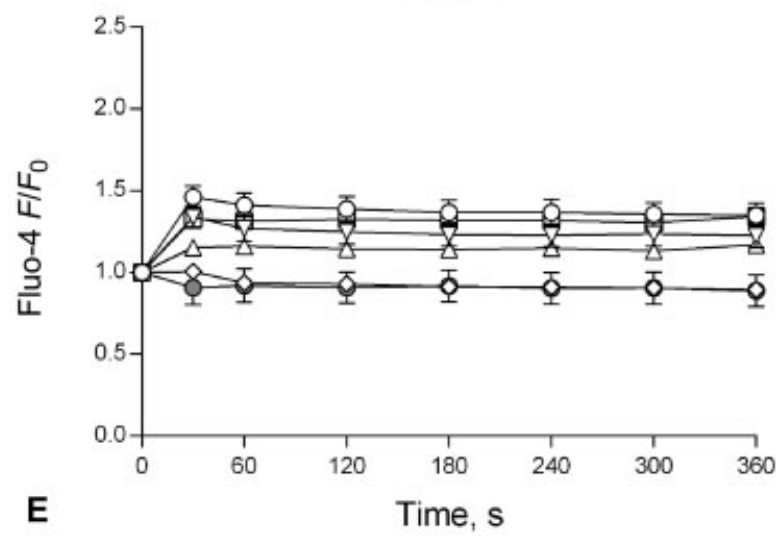

$\mathrm{H}_{2} \mathrm{O}_{2}$

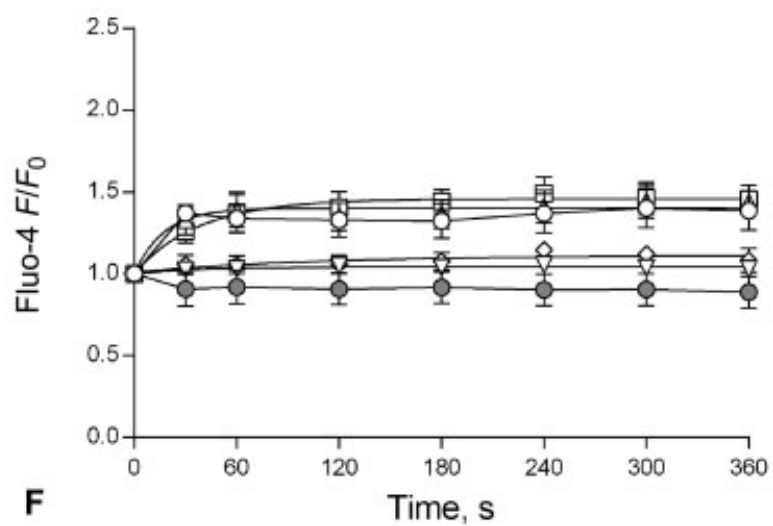

Fig. 2 Agonist-dependent intracellular $\mathrm{zinc}\left(\left[\mathrm{Zn}^{2+}\right]_{\mathrm{i}}\right)$ fluctuations are sensitive to the platelet redox state. Platelets were loaded with Fz-3 (A, B, C), or Fluo-4 (D, E, F) and stimulated with CRP-XL $(1 \mu \mathrm{g} / \mathrm{mL}, \mathrm{O}, \mathrm{A}, \mathrm{D}), \mathrm{U} 46619(10 \mu \mathrm{M}, \bigcirc \mathrm{B}, \mathrm{E})$ or $\mathrm{H}_{2} \mathrm{O}_{2}(10 \mu \mathrm{M}, \mathrm{O}, \mathrm{C}, \mathrm{F})$, during which changes in fluorescence were monitored. Where indicated, platelets were pre-treated with TPEN $(\nabla, 50 \mu \mathrm{M})$, DM-BAPTA $(\diamond, 10 \mu \mathrm{M})$, PEG-SOD $(\square, 30 \mathrm{U} / \mathrm{mL})$, PEG-CAT $(\triangle, 300 \mathrm{U} / \mathrm{mL})$ or vehicle (DMSO), ๑). Data are mean \pm standard error of the mean (SEM) from at least 5 independent experiments. Significance is denoted as ${ }^{* * *} p<0.001$, ${ }^{* *} p<0.01$ or ${ }^{*} p<0.05$.

Further experiments were performed to resolve the relationship between the platelet redox state and $\left[\mathrm{Zn}^{2+}\right]_{\mathrm{i}}$ fluctuations. Treatment with $\mathrm{H}_{2} \mathrm{O}_{2}$ mimics increases in platelet reactive oxygen species (ROS). ${ }^{19} \mathrm{H}_{2} \mathrm{O}_{2}$ increased both $\left[\mathrm{Ca}^{2+}\right]_{\mathrm{i}}$ and $\left[\mathrm{Zn}^{2+}\right]_{\mathrm{i}}\left(F / F_{0}\right.$ plateaus were $1.8+0.3 \mathrm{AU}$ following $\mathrm{H}_{2} \mathrm{O}_{2}$ $[10 \mu \mathrm{M}]$ stimulation of Fz3-loaded platelets, compared with $0.9 \pm 0.1 \mathrm{AU}$ for vehicle-treated platelets, while $\mathrm{H}_{2} \mathrm{O}_{2}$ sti- mulation increased Fluo-4 fluorescence from $0.9 \pm 0.1$ to $1.4 \pm 0.1 \mathrm{AU}, p<0.05$, - Fig. 2 C, F). $\mathrm{H}_{2} \mathrm{O}_{2}$-mediated $\left[\mathrm{Zn}^{2+}\right]_{i}$ increases were abrogated with PEG-SOD or PEG-CAT, while $\left[\mathrm{Ca}^{2+}\right]_{\mathrm{i}}$ was unaffected $(\boldsymbol{-}$ Fig. 2E, $\mathbf{F})$. These data support a role for the platelet redox state in regulating $\left[\mathrm{Zn}^{2+}\right]_{\mathrm{i}}$ fluctuations.

Having demonstrated that intra-platelet $\mathrm{Zn}^{2+}$ rises in response to agonist stimulation, we further examined the 
influence of $\left[\mathrm{Zn}^{2+}\right]_{i}$ on platelet responses. We hypothesized that liberation of $\mathrm{Zn}^{2+}$ from intracellular stores (such as platelet $\alpha$-granules ${ }^{20}$ ) using specific ionophores would result in increased $\left[\mathrm{Zn}^{2+}\right]_{\mathrm{i}}$, in a similar manner A23187-evoked $\mathrm{Ca}^{2+}$ responses. ${ }^{21} \mathrm{Zn}^{2+}$ ionophores $\mathrm{Cq}$ and Py have previously been used to model $\left[\mathrm{Zn}^{2+}\right]_{\mathrm{i}}$ increases in nucleated cells. $22-24$ We utilized these reagents to model agonistevoked $\left[\mathrm{Zn}^{2+}\right]_{\mathrm{i}}$ increases in washed platelet suspensions. Stimulation with $\mathrm{Cq}$ or Py produced large elevations of $\left[\mathrm{Zn}^{2+}\right]_{\text {i }}$, with $F / F_{0}$ plateaus of $7.9 \pm 0.5$ and $3.3 \pm 0.3 \mathrm{AU}$, respectively $\left(p<0.05\right.$, - Fig. 3A, B). The extent of $\left[\mathrm{Zn}^{2+}\right]_{i}$ increase was greater than that observed following CRP-XL stimulation, suggesting that liberation from stores is not the principal means by which $\left[\mathrm{Zn}^{2+}\right]_{\mathrm{i}}$ increases following agonist stimulation. $\mathrm{Zn}^{2+}$ ionophore-dependent Fz-3 fluorescence increases were sensitive to pre-treatment with TPEN or BAPTA, consistent with a role for $\mathrm{Cq}$ or Py increasing $\left[\mathrm{Zn}^{2+}\right]_{\mathrm{i}}$ (-Fig. 3A, B). However, $\left[\mathrm{Zn}^{2+}\right]_{\mathrm{i}}$ signals were not influenced by PEG-SOD or PEG-CAT, demonstrating that ionophore-induced $\left[\mathrm{Zn}^{2+}\right]_{\mathrm{i}}$ release is not redox sensitive. $\mathrm{Cq}$ or Py stimulation did not affect Fluo-4 fluorescence ( - Fig. 3D, E), indicating that $\mathrm{Zn}^{2+}$ ionophores have a negligible affinity for $\mathrm{Ca}^{2+}$. A23187 increased Fluo-4 fluorescence (from $0.9 \pm 0.1$ to $5.8 \pm 0.9 \mathrm{AU}$ after 6 minutes, $p<0.05$, -Fig. 3F), but had no effect on Fz-3 fluorescence (- Fig. 3C), demonstrating that Fz-3 fluorescence is not affected by

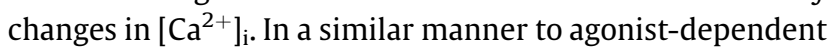
$\mathrm{Ca}^{2+}$ signalling, A23187-dependent $\left[\mathrm{Ca}^{2+}\right]_{\mathrm{i}}$ increases were abrogated by BAPTA, but were unaffected by TPEN. Thus, Fluo-4 fluorescence is not influenced by $\mathrm{Zn}^{2+}$.

Our data confirm that platelet $\left[\mathrm{Zn}^{2+}\right]_{\mathrm{i}}$ increases can be modelled using the $\mathrm{Zn}^{2+}$ ionophores $\mathrm{Cq}$ and Py. Next, we examined the influence of increases in $\left[\mathrm{Zn}^{2+}\right]_{i}$ on platelet aggregation. High concentrations of $\mathrm{Cq}(300 \mu \mathrm{M})$ resulted in an initial decrease in light transmission, followed by a substantial increase, consistent with shape change and aggregation. Platelet aggregates were present following visual inspection of test cuvettes at the end of each experiment (not shown). The extent of Cq-induced aggregation $(300 \mu \mathrm{M}, 27.8 \pm 5.0 \%)$ was lower than that for A23187 (300 $\mu \mathrm{M}, 70.2 \pm 8.6 \%, p<0.05$, - Fig. 4A, B). Treatment with lower concentrations of $\mathrm{Cq}(30 \mu \mathrm{M})$ resulted in shape change only, with no progression to aggregation. Py stimulation did not cause aggregation but did result in shape change ( - Fig. 4A-C). Response to Py were biphasic, with intermediate concentrations $(10-30 \mu \mathrm{M})$ resulting in shape change, and higher concentrations having no effect.

The degree of shape change was quantified by calculating the lowest light transmission during ionophore-induced aggregation (denoted minimum aggregation, \%). Shape change following Cq or A213817 treatment was comparable (minimum aggregation for $30 \mu \mathrm{M} \mathrm{Cq}$ or Py was $-13.3 \pm 2.9$ and $-27.5 \pm 2.2 \%$, respectively, compared with $-15.1 \pm 2.7 \%$ for $30 \mu \mathrm{M}$ A23187, ns, - Fig. 4C). These data are consistent with a role for $\left[\mathrm{Zn}^{2+}\right]_{\mathrm{i}}$ in regulating cytoskeletal changes in a similar manner to $\left[\mathrm{Ca}^{2+}\right]_{\mathrm{i}}$-induced shape change.

To confirm that the changes in light transmission were a biological, rather than chemical phenomenon, we took a pharmacological approach by pre-treating platelets with the actin polymerization inhibitor Cyt-D prior to ionophore stimulation. Cyt-D abrogated Cq-, Py- and A23187-induced shape change, consistent with a genuine biological effect. The minimum aggregation for Cyt-D treated and untreated platelets were $-5.7 \pm 2.1$ and $-16.7 \pm 1.9 \%$, respectively, following $\mathrm{Cq}$ stimulation, $-9.1 \pm 1.9$ and $-33.2 \pm 2.4$, respectively, following Py stimulation, and $-3.7 \pm 1.4$ and $-13.0 \pm 1.8 \%$,
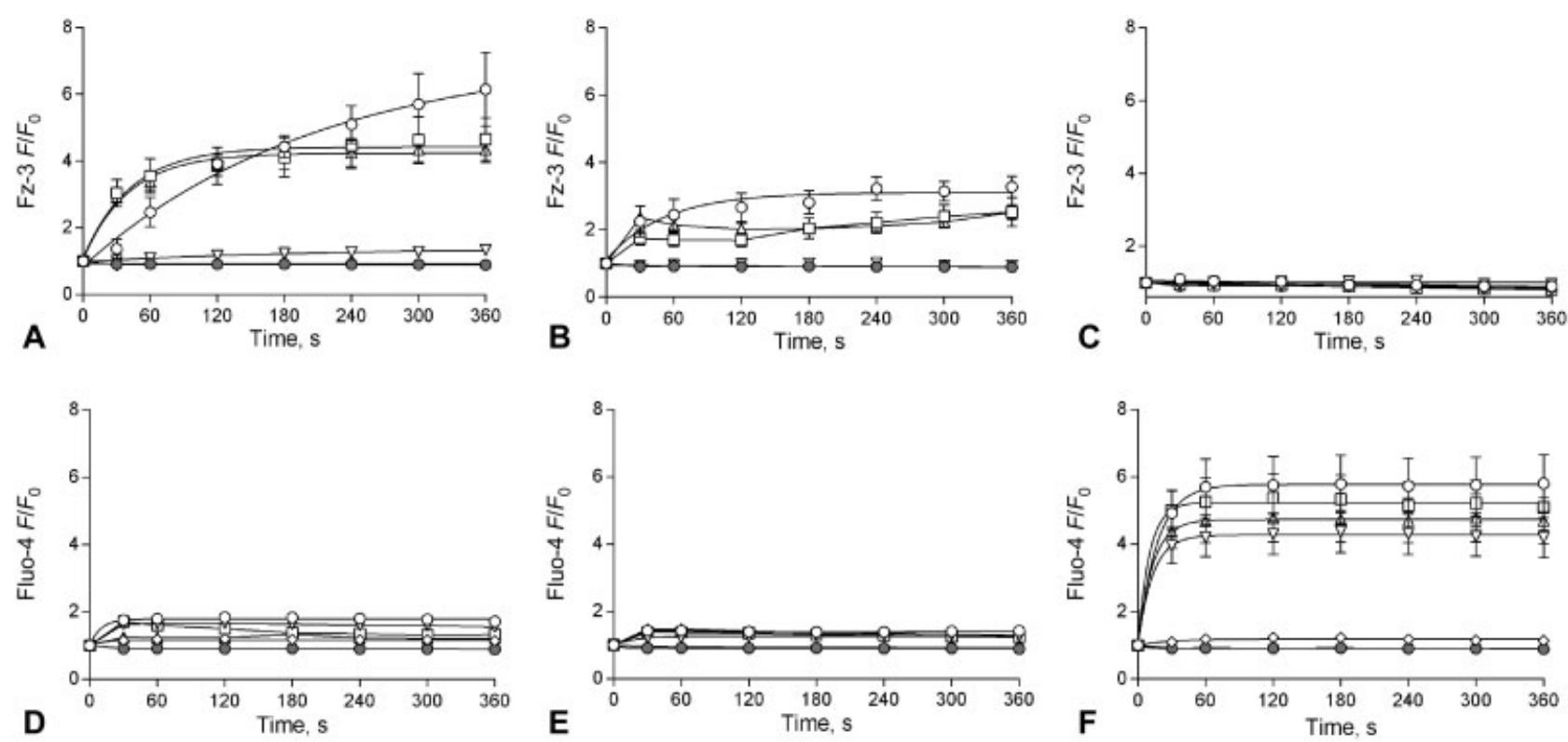

Fig. 3 Treatment of platelets with $\mathrm{Zn}^{2+}$ ionophores clioquinol (Cq) or pyrithione (Py) elevates $\left[\mathrm{Zn}^{2+}\right]_{\mathrm{i}}$, but not $\left[\mathrm{Ca}^{2+}\right]_{\text {. }}$. Washed platelet suspensions were loaded with Fz-3 (A, B, C), or Fluo-4 (D, E, F) and stimulated with Cq (O, $300 \mu \mathrm{M}, \mathrm{A}, \mathrm{D}), \mathrm{Py}(\mathrm{O}, 300 \mu \mathrm{M}, \mathrm{B}, \mathrm{E})$ or A23187 (O, C, F). Where indicated, platelets were pre-treated with (TPEN) $(50 \mu \mathrm{M}, \nabla)$, DM-BAPTA $(10 \mu \mathrm{M}, \diamond)$, PEG-SOD $(30 \mathrm{U} / \mathrm{mL}, \square)$, PEG-CAT $(300 \mathrm{U} / \mathrm{mL}, \triangle)$, or vehicle (DMSO), - Data are mean \pm standard error of the mean (SEM) from at least 6 independent experiments. Significance is denoted as ${ }^{* * *} p<0.001,{ }^{* *} p<0.01$ or ${ }^{*} p<0.05$. 


\section{$\mathrm{Cq}$}

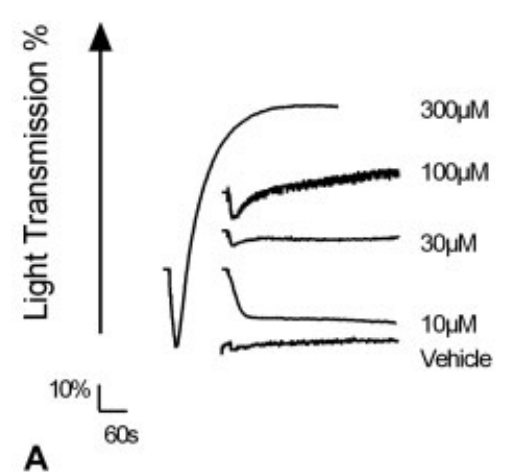

A

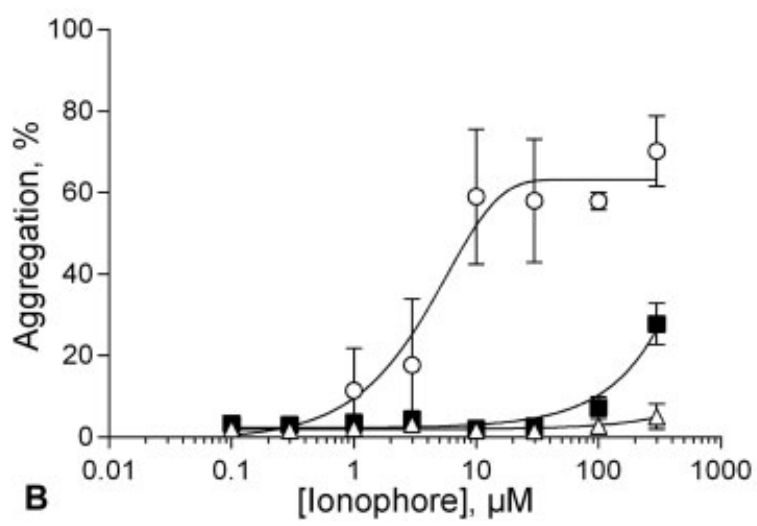

Py

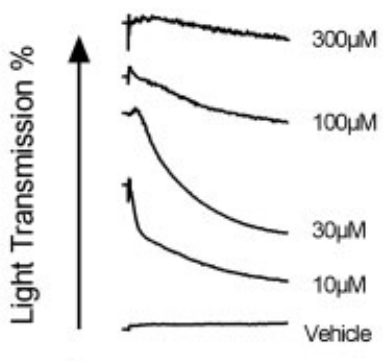

${ }^{10 \%} L_{60 s}$
A23187

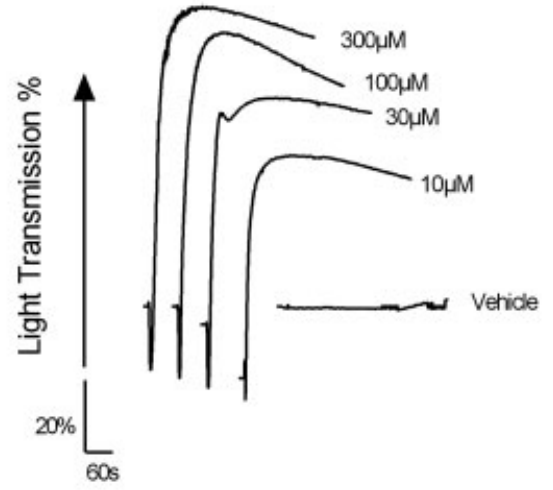

Fig. 4 Stimulation of platelets with $\mathrm{Zn}^{2+}$ ionophores leads to shape change. (A) Washed platelet suspensions were stimulated with different concentrations of clioquinol (Cq), pyrithione (Py) or A23187 during which changes in light transmission were monitored using optical aggregometry. Initial downward deflections indicate a reduction in light transmission that are consistent with shape change. Subsequent upward deflections indicate increases in light transmission, consistent with platelet aggregation. The maximum (B) and minimum (C) extent of aggregation were calculated for each ionophore

( $\square \mathrm{Cq}, \triangle \mathrm{Py}, \mathrm{O}$ A23187). Data are mean \pm standard error of the mean (SEM) from at least 5 experiments.

respectively, following A23187 stimulation ( $30 \mu \mathrm{M}, p<0.05$,

-Fig. 5A, B). Pre-treatment of platelets with TPEN abrogated Cq- or Py-induced shape change but had no effect on A23187 treatment (minimum aggregation following TPEN treatment was $-4.9 \pm 1.2,-11.1 \pm 2.3$ and $-17.9 \pm 2.6 \%$ for $C q$, Py and
A23817, respectively, $p<0.05$, - Fig. 5A, B). These data are consistent with a role for $\left[\mathrm{Zn}^{2+}\right]_{\mathrm{i}}$ in regulating cytoskeletal rearrangements. The resistance of A23187-induced shape change to TPEN treatment suggests that the contribution of $\mathrm{Ca}^{2+}$ signals to cytoskeletal re-arrangement occurs
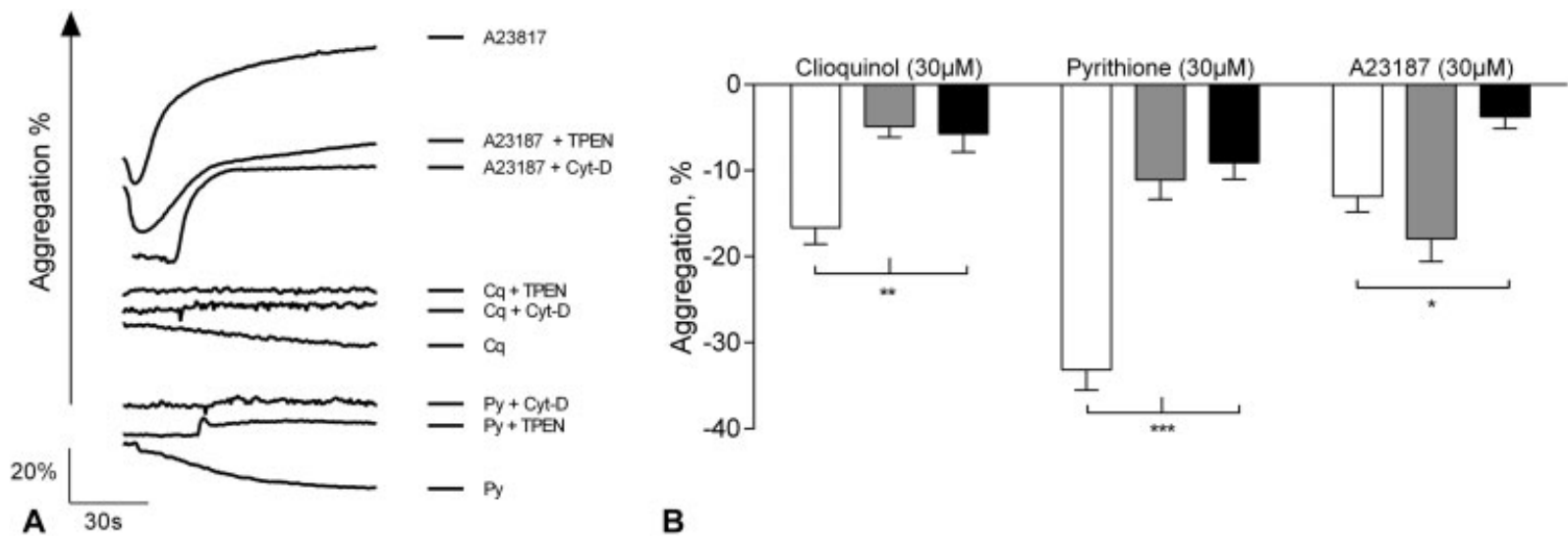

B

Fig. 5 lonophore-induced shape change is sensitive to pre-treatment with (Cyt-D) or TPEN. (A) Representative aggregometry traces showing

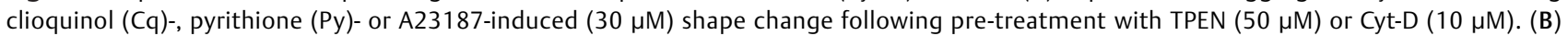
Quantitation of minimum aggregation following treatment of platelets pre-treated with TPEN ( $25 \mu \mathrm{M})$, Cyt-D ( $\square 10 \mu \mathrm{M})$ or vehicle ( $\square$ DMSO, prior to stimulation with Cq, Py or A23187 (30 $\mu \mathrm{M})$. Data are mean \pm standard error of the mean (SEM) of at least 6 experiments. Significance is denoted as ${ }^{* * *} p<0.001,{ }^{* *} p<0.01$ or ${ }^{*} p<0.05$. 
independently of $\mathrm{Zn}^{2+}$ signals, and could indicate different mechanisms for $\mathrm{Zn}^{2+}$ - and $\mathrm{Ca}^{2+}$-induced shape change.

$\left[\mathrm{Zn}^{2+}\right]_{\mathrm{i}}$-dependent cytoskeletal changes were further investigated by visualizing platelet spreading on fibrinogen. TPEN-treated platelets were able to adhere to fibrinogen, but did not spread, with no visible lamellipodia or filopodia ( -Fig. 6A). Mean platelet surface coverage after 10 minutes was $12.8 \pm 1.5 \mu \mathrm{m}$, compared with $22.7 \pm 1.6 \mu \mathrm{m}$ for untreated platelets (-Fig. 6B). Regulation of Cq-induced shape change was investigated by assaying VASP and MLC, which alter phosphorylation status during cytoskeletal rearrangements. $^{25,26} \mathrm{Cq}$ - or Py-induced shape change were accompanied by increased phosphorylation of ser157 of MLC, confirming a role for $\left[\mathrm{Zn}^{2+}\right]_{\mathrm{i}}$ in the signalling process leading to cytoskeletal changes. Unlike $\mathrm{PGE}_{1}$ treatment, VASP did not undergo phosphorylation in response to ionophore treatment, indicating that $\mathrm{Zn}^{2+}$ does not influence activity of cyclic nucleotide-dependent kinases such as protein kinase $A$ (PKA) or protein kinase $\mathrm{G}(\mathrm{PKG}){ }^{27}$

These data indicate that increases in $\left[\mathrm{Zn}^{2+}\right]_{\mathrm{i}}$ initiate platelet activation events, such as shape change and aggregation. To better understand the extent to which changes in $\left[\mathrm{Zn}^{2+}\right]_{\mathrm{i}}$ regulate platelet activation, the influence of $\mathrm{Cq}$ treatment on conventional markers of platelet activation

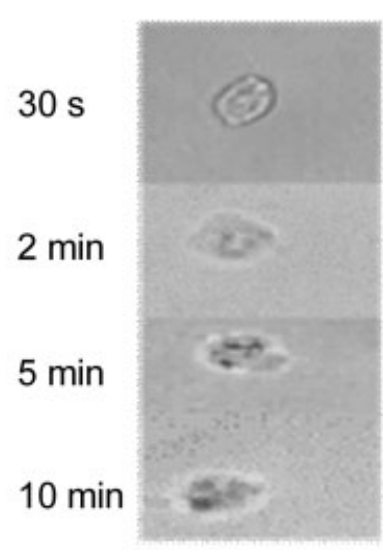

A 50 $\mu \mathrm{M}$ TPEN

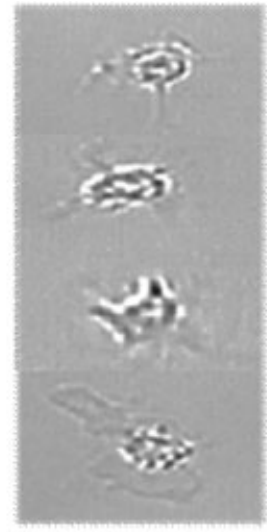

Vehicle

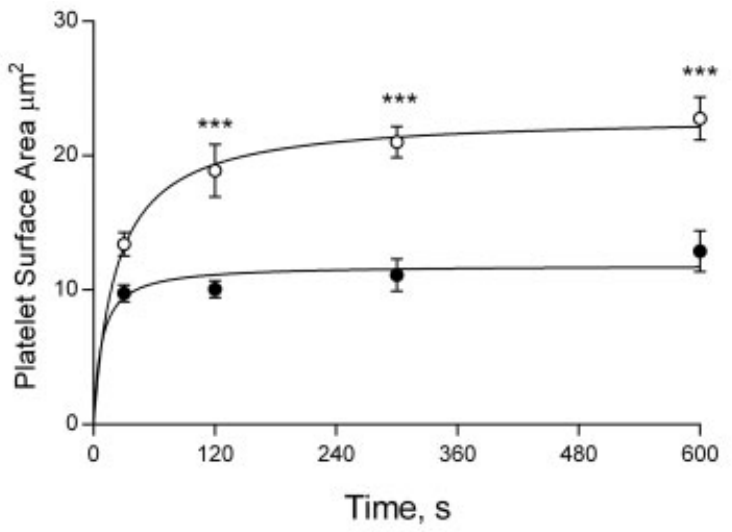

B
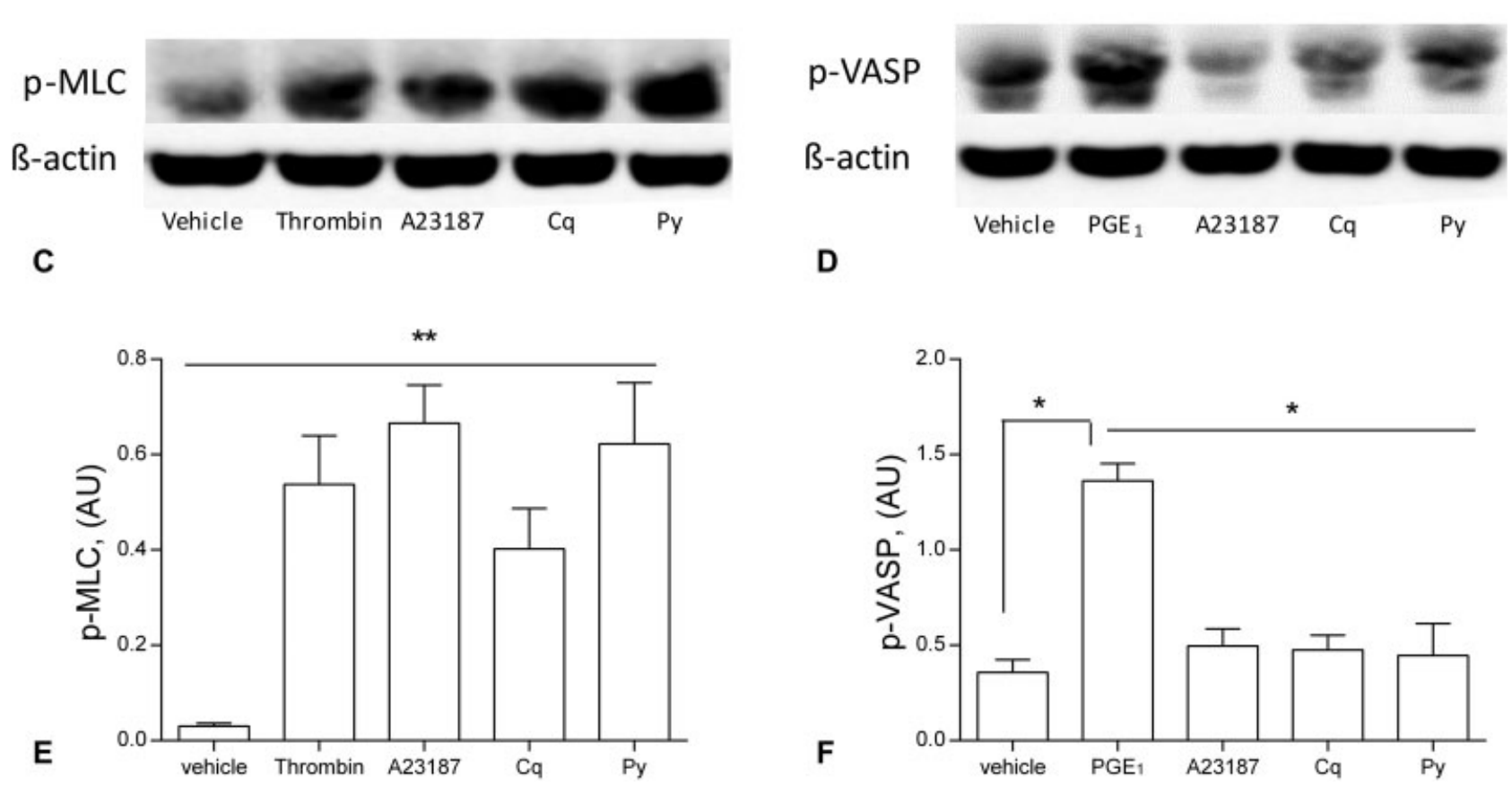

Fig. $6\left[\mathrm{Zn}^{2+}\right]_{i}$ regulates platelet shape change, and phosphorylation of cytoskeletal regulators. Washed platelet suspensions were incubated on fibrinogen-coated coverslips following pre-treatment with $50 \mu \mathrm{M}$ TPEN or vehicle control (DMSO). (A) Representative images of platelet spreading. (B) Quantification of the surface coverage by adherent platelets (O DMSO, $-50 \mu \mathrm{M}$ TPEN, $n=3$ ). (C) Representative Western blot showing increased MLC phosphorylation following stimulation of platelets for 2 minutes with vehicle (DMSO), thrombin (1 U/mL), A23187 $(100 \mu \mathrm{M})$, clioquinol $(\mathrm{Cq})(300 \mu \mathrm{M})$ and pyrithione (Py) $(300 \mu \mathrm{M})$. (D) Representative Western blot showing VASP phosphorylation following stimulation of platelets for 2 minutes with vehicle (DMSO), prostaglandin $\mathrm{E}_{1}\left(\mathrm{PGE}_{1}\right)(1 \mathrm{U} / \mathrm{mL}), \mathrm{A} 23187(100 \mu \mathrm{M}), \mathrm{Cq}(300 \mu \mathrm{M})$ and Py $(300 \mu \mathrm{M})$. VASP phosphorylation was unaffected by $\mathrm{Zn}^{2+}$ ionophore treatment. Blots are representative of three experiments. Data are means \pm standard error of the mean (SEM), from at least 5 independent experiments. Significance is denoted as ${ }^{* * *} p<0.001,{ }^{* *} p<0.01$ or ${ }^{*} p<0.05$. 
was investigated. In a similar manner to thrombin and A23187, Cq or Py stimulation $(300 \mu \mathrm{M})$ substantially increased platelet PAC-1 binding $(59.7 \pm 5.5,64.5 \pm 5.8$, $47.3 \pm 4.1$ and $37.8 \pm 5.0 \%$, respectively, $\quad p<0.05$, -Fig. 7A), consistent with earlier observations correlating Cq stimulation with aggregation ( - Fig. 4), and supportive of a role for $\left[\mathrm{Zn}^{2+}\right]_{\mathrm{i}}$ in $\alpha_{\mathrm{IIb}} \beta_{3}$ activation. Cq or Py increased CD63, but not CD62P externalization $(55.9 \pm 7.8$ and $5.7 \pm 2.8 \%$, respectively, following $\mathrm{Cq}$ stimulation, and $50.2 \pm 2.6$ and $6.9 \pm 2.2 \%$ following Py stimulation, - Fig. 7A) indicating that increases in $\left[\mathrm{Zn}^{2+}\right]_{\mathrm{i}}$ initiate dense, but not $\alpha$ granule, secretion. This differed from both thrombin (CD62P:
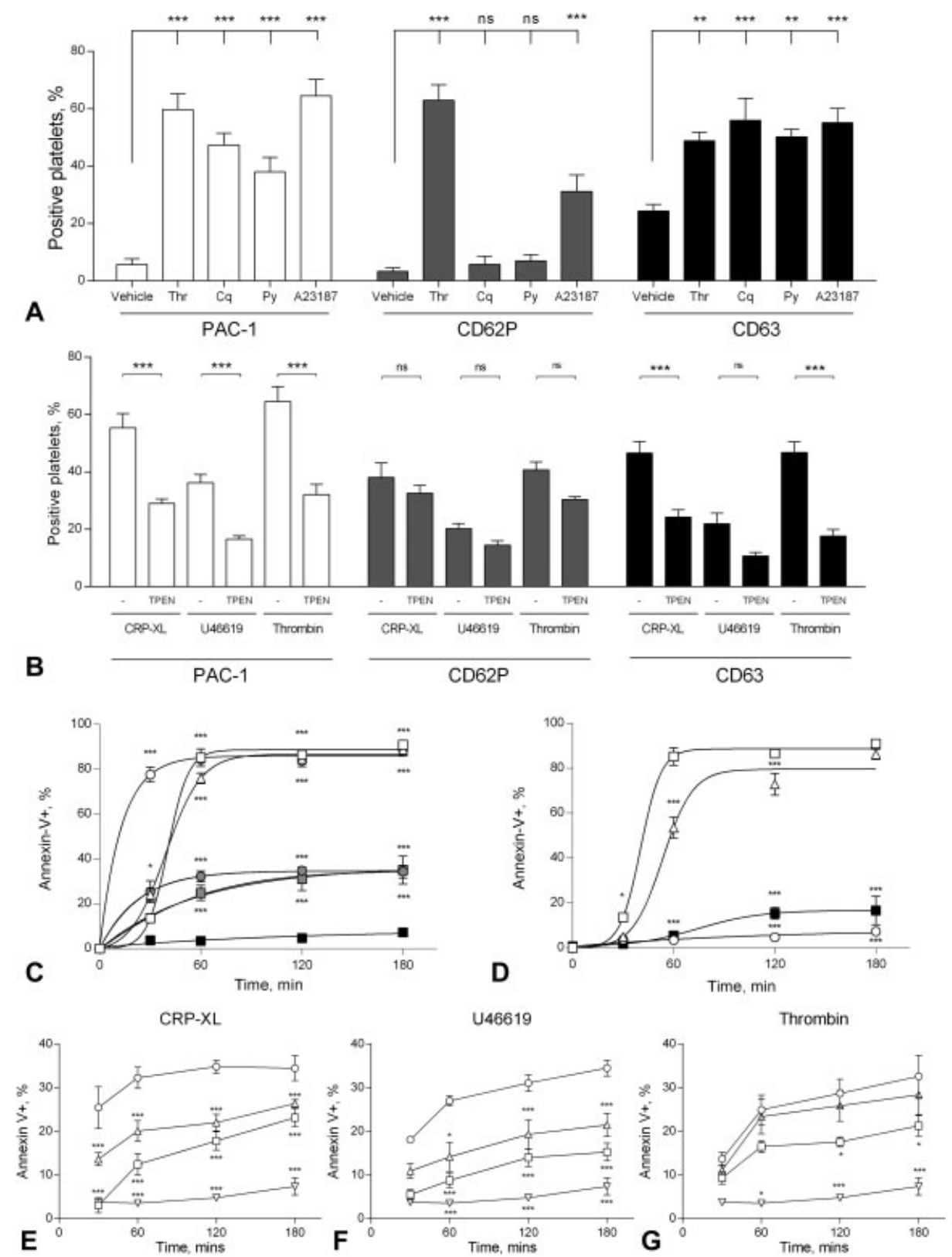

Fig. 7 Increasing platelet $\left[\mathrm{Zn}^{2+}\right]_{i}$ using $\mathrm{Zn}^{2+}$ ionophores increases platelet activation markers. (A) Washed platelet suspensions were stimulated by thrombin (Thr, $1 \mathrm{U} / \mathrm{mL}$ ), clioquinol (Cq) $(300 \mu \mathrm{M})$, pyrithione (Py) $(300 \mu \mathrm{M})$ or A23187 (100 $\mu \mathrm{M})$ and changes of PAC-1 (white), CD62P (grey) and CD63 (black) binding were obtained after 60 minutes. (B) Washed platelet suspensions were stimulated by CRP-XL $(1 \mu \mathrm{g} / \mathrm{mL}), \mathrm{U} 46619$ $(10 \mu \mathrm{M})$ or thrombin $(1 \mathrm{U} / \mathrm{mL})$, following pre-treatment with TPEN $(50 \mu \mathrm{M})$, and changes of PAC-1 (white), CD62P (grey) and CD63 (black) binding were obtained after 60 minutes. (C) Washed platelet suspensions were treated with $\mathrm{Ca}^{2+}$ or $\mathrm{Zn}^{2+}$ ionophores, or conventional platelet agonists, prior to analysis of annexin-V binding by flow cytometry. $\square$ Clioquinol $(300 \mu \mathrm{M}), \triangle$ pyrithione $(300 \mu \mathrm{M}), \circ \mathrm{A} 23187(300 \mu \mathrm{M}), \bullet \mathrm{CRP}$ $(1 \mu \mathrm{g} / \mathrm{mL}), \boldsymbol{\square}$ thrombin, $(1 \mathrm{U} / \mathrm{mL}), \boldsymbol{\square}$ vehicle (DMSO). (D) Platelet suspensions were pre-treated with the caspase inhibitor Z-VAD $(\triangle, 1 \mu \mathrm{M})$, the $\mathrm{Zn}^{2+}$ chelator, TPEN $(\boldsymbol{\square}, 25 \mu \mathrm{m})$ or vehicle $(\square)$ prior to stimulation with clioquinol $(300 \mu \mathrm{M})$. $O$ Unstimulated platelets. Changes in the percentage of platelets binding to annexin- $V$ were recorded. Washed platelets suspensions were pre-treated with Z-VAD ( $1 \mu \mathrm{M})$, or TPEN (50 $\mu \mathrm{M})$ prior to stimulation with conventional agonists, CRP-XL $(1 \mu \mathrm{g} / \mathrm{mL}, \mathrm{E}), \mathrm{U} 46619(10 \mu \mathrm{M}, \mathrm{F})$ or thrombin $(1 \mathrm{U} / \mathrm{mL}, \mathrm{G})$. Changes in annexin-V binding were monitored using flow cytometry. O Vehicle, $\square$ Z-VAD $(1 \mu \mathrm{M}), \triangle \operatorname{TPEN}(50 \mu \mathrm{M}), \nabla \mathrm{DMSO}$ (no agonist). Data are means \pm standard error of the mean (SEM) of at least 3 independent experiments. Significance is denoted as ${ }^{* * *} p<0.001,{ }^{* *} p<0.01$ or ${ }^{*} p<0.05$. 
$62.9 \pm 5.5 \%, \quad$ CD63: $48.8 \pm 3.0 \%$ ) and A23187 (CD62P: $31.1 \pm 5.7 \%, \mathrm{CD} 63: 55.1 \pm 5.0 \%$, which also regulate $\alpha$ and dense granule release.

Further experiments were performed to assess the influence of $\left[\mathrm{Zn}^{2+}\right]_{i}$ on agonist-evoked changes in platelet activatory markers. TPEN reduced increases of PAC-1, or CD63 binding in response to CRP-XL $(1 \mu \mathrm{gg} / \mathrm{mL}$, from $55.4 \pm 4.9$ to $29.0 \pm 1.5 \%$ for PAC-1 binding, and from $46.4 \pm 4.0$ to $24.2 \pm 2.5 \%$ for CD63 binding, $p<0.05)$, U46619 $(10 \mu \mathrm{M}$, from $36.2 \pm 2.8$ to $16.5 \pm 1.2 \%$ for PAC-1 binding, and from $21.9 \pm 3.6$ to $10.7 \pm 1.3 \%$ for CD63 binding, $p<0.05$ ) or thrombin $(1 \mathrm{U} / \mathrm{mL}$, from $64.6 \pm 5.2$ to $32.1 \pm 3.6 \%$ for PAC1 binding, and from $46.8 \pm 3.8$ to $17.6 \pm 2.3 \%$ for CD63 binding, $p<0.05$ ), but had no effect on agonist-evoked CD62P increases (-Fig. 7B). This provides further support for a role of $\left[\mathrm{Zn}^{2+}\right]_{i}$ in differentially regulating platelet granule secretion.

Extracellular $\mathrm{Zn}^{2+}$ signalling and agonist-induced changes in $\left[\mathrm{Zn}^{2+}\right]_{\mathrm{i}}$ have both been linked to apoptosis and related responses in nucleated cells. ${ }^{28-31}$ However, the role of $\mathrm{Zn}^{2+}$ in PS exposure during platelet activation has yet to be studied. To investigate the influence of $\left[\mathrm{Zn}^{2+}\right]_{i}$ on PS exposure, platelets were treated with ionophores, and annexin- $V$ binding was quantified in real time. Increasing platelet $\left[\mathrm{Zn}^{2+}\right]_{\mathrm{i}}$ with $\mathrm{Cq}(300 \mu \mathrm{M})$ resulted in a concurrent increase in annexin- $\mathrm{V}$ binding. PS exposure evolved more slowly with $\mathrm{Zn}^{2+}$ ionophore treatment than A23817, but reached similar plateau levels $(90.0 \pm 0.9$ and $88.6 \pm 2.7 \%$ for $\mathrm{Cq}$ and A23187, respectively, - Fig. 7C), indicating that most platelets in the population were annexin- $\mathrm{V}$ positive. This differed in responses to conventional agonists, thrombin and CRP-XL, which induced PS exposure in a sub-set of platelets ( $35.0 \pm 6.2$ and $34.4 \pm 6.2 \%$, respectively). Cq-induced annexin-V binding was sensitive to TPEN $(6.6 \pm 6.3 \%$ positive platelets at 60 minutes) confirming a role for $\mathrm{Zn}^{2+}$. Furthermore, pre-treatment with the caspase inhibitor, Z-VAD, abrogated Cq-induced PS exposure $(53.6 \pm 4.7 \%$ at $60 \mathrm{~min}$ utes, $p<0.05,-$ Fig. 7D). The influence of $\mathrm{Zn}^{2+}$ on agonistevoked annexin-V binding was also investigated. Consistent with the findings of Cohen et al, ${ }^{32}$ we observed a reduction in agonist-evoked PS exposure in the presence of Z-VAD $(1 \mu \mathrm{M})$ (from $34.4 \pm 2.9$ to $23.1 \pm 2.0 \%$ following stimulation with $1 \mu \mathrm{g} / \mathrm{mL}$ CRP-XL, from $24.4 \pm 1.8$ to $15.2 \pm 2.0 \%$ following stimulation with $10 \mu \mathrm{M}$ U46619 and from $32.5 \pm 4.8$ to $21.2 \pm 2.4 \%$ following stimulation with $1 \mathrm{U} / \mathrm{mL}$ thrombin, - Fig. 7E-G, $p<0.05$ ). Similar reductions of annexin-V binding in TPEN-treated platelets were observed following stimulation by CRP-XL $(26.3 \pm 0.9 \%, p<0.05)$, or U46619 $(21.4 \pm 2.7 \%, p<0.05)$. However, TPEN did not affect thrombin-mediated annexin- $\mathrm{V}$ binding $(28.3 \pm 4.6 \%$, ns). These data are consistent with a role for $\mathrm{Zn}^{2+}$ in agonist-evoked PS exposure.

\section{Discussion}

The role of $\mathrm{Zn}^{2+}$ as a secondary signalling molecule has received little research interest, possibly owing to its relatively low resting cytosolic levels (pM, compared with nM concen- trations of $\left.\mathrm{Ca}^{2+}\right) \cdot \mathrm{Zn}^{2+}$ is present in granules of nucleated cells, and in platelet $\alpha$ granules. It also associates with thiol-containing proteins such as metallothioneins, which are also present in platelets. ${ }^{33}$ The transition between protein- or membranebound $\mathrm{Zn}^{2+}$ and labile $\mathrm{Zn}^{2+}$ in the cell cytosol has been demonstrated in multiple cell systems, and increases in labile $\left[\mathrm{Zn}^{2+}\right]_{\mathrm{i}}$ have been correlated with phenotypic changes. Here, we show for the first time that agonist-evoked stimulation of platelets in vitro results in increases of $\left[\mathrm{Zn}^{2+}\right]_{\mathrm{i}}$. While requiring further confirmation, such behaviour is consistent with a role of $\mathrm{Zn}^{2+}$ as a secondary messenger. $\mathrm{Zn}^{2+}$ fluctuations were apparent in the presence of extracellular $\mathrm{CaCl}_{2}$, supporting a physiological role for this effect. We confirm the nature of the fluorescent signal using the high affinity $\mathrm{Zn}^{2+}$ chelator TPEN. TPEN was also used to probe the role of $\mathrm{Zn}^{2+}$ in functional responses to agonist stimulation. Owing to its affinity for $\mathrm{Zn}^{2+}$, use of TPEN here is not only likely to abrogate agonist-evoked increases in $\left[\mathrm{Zn}^{2+}\right]_{\mathrm{i}}$, but could also strip metalloproteins of $\mathrm{Zn}^{2+}$ co-factors. ${ }^{34}$ Thus, conclusions drawn from the use of TPEN may not only reflect abrogation of agonist-evoked $\left[\mathrm{Zn}^{2+}\right]_{\mathrm{i}}$ increases. $\left[\mathrm{Zn}^{2+}\right]_{\mathrm{i}}$ increases were observed in platelets following stimulation via GpVI and TP, but not via PAR, indicating that different signalling pathways link to $\left[\mathrm{Zn}^{2+}\right]_{\mathrm{i}}$ release. Signalling via GpVI differs from that of TP or PAR G-protein-coupled receptors, in that it results in tyrosine phosphorylation of platelet proteins (such as Syk and LAT), leading to activation of PI3K and PLCY2. Conversely, PAR and TP signal through Gprotein-dependent routes to activate Rho-GEF and PLC $\beta$. It is likely that $\left[\mathrm{Zn}^{2+}\right]_{\mathrm{i}}$ increases are regulated by signalling proteins that are not shared by GpVI and thrombin pathways. However, the different outcomes following PAR and TP-dependent signalling are harder to reconcile, as both receptors couple to similar signalling pathways that involve $G \alpha_{12 / 13}$ and $G \alpha_{\mathrm{q}}$.

We show that the platelet redox state effects $\left[\mathrm{Zn}^{2+}\right]_{i}$ fluctuations in a similar manner to nucleated cells. ${ }^{35,36}$ CRP-XLand U46619-evoked elevations of $\left[\mathrm{Zn}^{2+}\right]_{\mathrm{i}}$ were sensitive to antioxidants, and could be enhanced by $\mathrm{H}_{2} \mathrm{O}_{2} \cdot \mathrm{Zn}^{2+}$ binding to thiols (e.g. metallothioneins) is redox-sensitive and changes of redox state lead to release of $\mathrm{Zn}^{2+}$ into the labile pool in nucleated cells. ${ }^{37}$ Given that modulation of the platelet redox state led to a rapid and sustained rise of $\left[\mathrm{Zn}^{2+}\right]_{\mathrm{i}}$, it is possible that platelet $\mathrm{Zn}^{2+}$-binding proteins represent a store for these cations. Interestingly, $\mathrm{Ca}^{2+}$ signalling was unaffected by redox changes, suggesting that these ions are differentially regulated. Indeed, the predominant $\mathrm{Ca}^{2+}$ store is the dense tubular system, which performs a similar role to the endoplasmic reticulum in nucleated cells. It is therefore likely that intraplatelet $\mathrm{Zn}^{2+}$ is stored by $\mathrm{Zn}^{2+}$-binding proteins and becomes liberated upon agonist stimulation. However, we did not observe increases of $\left[\mathrm{Zn}^{2+}\right]_{i}$ following thrombin stimulation, which has been shown to induce similar levels of ROS activation as collagen activation. ${ }^{18,38}$ One possible explanation could be that the larger $\mathrm{Ca}^{2+}$ signal generated by thrombin negatively regulates $\mathrm{Zn}^{2+}$ release.

We examined the influence of $\left[\mathrm{Zn}^{2+}\right]_{\mathrm{i}}$ on activatory processes using membrane permeable $\mathrm{Zn}^{2+}$-specific ionophores, Py and Cq, which have been widely used to model increases in $\left[\mathrm{Zn}^{2+}\right]_{i}$. Stimulation with either ionophore 
resulted in increases in $\left[\mathrm{Zn}^{2+}\right]_{\mathrm{i}}$, with a greater signal obtained with Cq. Neither ionophore produced increases in Fluo-4 fluorescence, indicating a negligible affinity for $\left[\mathrm{Ca}^{2+}\right]_{\mathrm{i}}$. Conversely, stimulation with the $\mathrm{Ca}^{2+}$ ionophore $\mathrm{A} 23187$ produced rapid increases in $\left[\mathrm{Ca}^{2+}\right]_{\mathrm{i}}$, but did not affect $\left[\mathrm{Zn}^{2+}\right]_{\mathrm{i}}$. Investigation of cation responses in cells depends heavily on the specificity of reagents for their cognate ions. By showing that $\mathrm{A} 23187$ initiates a $\mathrm{Ca}^{2+}$ response which is not detected by $\mathrm{Fz}$-3, we demonstrate that $\mathrm{Fz}-3$ fluorescence increases are directly attributable to changes in $\left[\mathrm{Zn}^{2+}\right]_{\mathrm{i}}$, and are not influenced by $\left[\mathrm{Ca}^{2+}\right]_{\mathrm{i}}$. This is further supported by our observation that TPEN does not affect Fluo-4 fluorescence, which also provides evidence that agonist-evoked $\mathrm{Ca}^{2+}$ signalling does not depend on $\left[\mathrm{Zn}^{2+}\right]_{i}$ signals. This observation raises questions about the relative roles of $\mathrm{Ca}^{2+}$ and $\mathrm{Zn}^{2+}$ in platelet activation, as both target similar proteins, including PKC, calmodulin and CamKII. ${ }^{4}$ Unlike agonist stimulation, ionophore-induced $\left[\mathrm{Zn}^{2+}\right]_{\mathrm{i}}$ increases were not sensitive to anti-oxidant treatment. Furthermore, the extent of $\left[\mathrm{Zn}^{2+}\right]_{\mathrm{i}}$ following ionophore stimulation was greater than that observed for agonists, indicating that ionophores liberate $\mathrm{Zn}^{2+}$ from stores that are not accessible to agonist-evoked signalling mechanisms. Such stores could include $\alpha$ granules, which are known to contain $\mathrm{Zn}^{2+} \cdot{ }^{20}$ Our use of ionophores here to model $\left[\mathrm{Zn}^{2+}\right]_{\mathrm{i}}$ increases while providing information on $\mathrm{Zn}^{2+}$-dependent mechanisms, is therefore unlikely to fully represent the physiological situation.

Cytoskeletal re-arrangements are primary steps in platelet activation. $\mathrm{Zn}^{2+}$ ionophore stimulation resulted in a demonstrable shape change, which was abrogated following Cyt-D treatment, verifying it as a biological, rather than chemical, response. Furthermore, platelet spreading on fibrinogen was abrogated following $\left[\mathrm{Zn}^{2+}\right]_{i}$ chelation. While not correlating $\left[\mathrm{Zn}^{2+}\right]_{\mathrm{i}}$ fluctuations with shape change, these data provide support for a role of $\mathrm{Zn}^{2+}$ in activation-dependent cytoskeletal re-arrangements. $\mathrm{Zn}^{2+}$ is an important regulator of the cytoskeleton in nucleated cells. ${ }^{39,40} \mathrm{Zn}^{2+}$ regulates tubulin polymerization leading to nuclear transport of transcription factors in neuronal cells, ${ }^{41}$ and has been shown to regulate the actin cytoskeleton, focal adhesion dynamics and cell migration in PC-3 and HeLa cells, ${ }^{35}$ where $\mathrm{Zn}^{2+}$ chelation supresses filopodia formation and results in the loss of stress fibres. Conversely, treatment with Py increased filopodia formation, supressed stress fibres and decreased the number and size of focal adhesions. ${ }^{35}$ Thus, $\mathrm{Zn}^{2+}$ is likely to play similar important roles in platelet cytoskeletal re-arrangements. We show that raising $\left[\mathrm{Zn}^{2+}\right]_{\mathrm{i}}$ results in increases in MLC phosphorylation. MLCK is canonically activated via $\mathrm{Ca}^{2+}$-mediated activation of calmodulin. ${ }^{42}$ As other calmodulin-dependent kinases have been shown to be modulated by $\mathrm{Zn}^{2+}$, it is possible that $\mathrm{Zn}^{2+}$ is able to substitute for $\mathrm{Ca}^{2+}$, initiating MLCK activation. ${ }^{43}$ Absence of phosphorylation of VASP indicates that increases in $\left[\mathrm{Zn}^{2+}\right]_{\mathrm{i}}$ do not influence the activity of cyclic nucleotidedependent kinases such as PKG or PKA.

Ionophore-induced elevation of $\left[\mathrm{Zn}^{2+}\right]_{\mathrm{i}}$ increased PAC-1 binding, supporting our aggregometry data (-Fig. 4), and supportive of role for $\mathrm{Zn}^{2+}$ in regulating $\alpha_{\mathrm{II}} \beta_{3}$ activity
(-Fig. 6). Interestingly, $\left[\mathrm{Zn}^{2+}\right]_{\mathrm{i}}$ increases resulted in the externalization of CD63, but not CD62P, supporting a role for $\mathrm{Zn}^{2+}$ in regulating $\alpha$, but not dense granule release. Further experiments using TPEN in conjunction with conventional platelet agonists provides support for a role for $\left[\mathrm{Zn}^{2+}\right]_{i}$ in $\alpha_{\mathrm{II}} \beta_{3}$ activation and dense granule secretion, but not $\alpha$ granule secretion ( - Fig. 7B). Distinct signalling pathways contribute to differential release of $\alpha$ and dense granules, and while the exact mechanism is poorly understood, our work provides evidence for a role for $\mathrm{Zn}^{2+}$ in these processes. ${ }^{44,45}$ While these studies show that $\mathrm{Zn}^{2+}$ fluctuations correlate with platelet behaviour, it should be noted that the physiological relevance of the ionophore-evoked $\left[\mathrm{Zn}^{2+}\right]_{\mathrm{i}}$ rises are unclear and that further work will be required to establish the significance of $\mathrm{Zn}^{2+}$-dependent secondary signalling in vivo. Upon stimulation with conventional agonists, a sub-set of platelets adopt pro-coagulant phenotypes, elevating $\left[\mathrm{Ca}^{2+}\right]_{i}$ and externalizing PS. Extracellular $\mathrm{Zn}^{2+}$ signalling, agonistinduced changes in $\left[\mathrm{Zn}^{2+}\right]_{i}$ and $\mathrm{Zn}^{2+}$ ionophore treatment have all been linked to apoptosis and related responses in nucleated cells. ${ }^{30,31,46-50}$ Here, we demonstrate that ionophore or agonist-evoked increases in platelet $\left[\mathrm{Zn}^{2+}\right]_{\mathrm{i}}$ results in PS exposure, consistent with the development of a procoagulant phenotype. Interestingly, while CRP-XL and U46619 evoked PS exposure was sensitive to $\mathrm{Zn}^{2+}$ chelation, thrombin stimulation was not. This provides further support for a role of $\mathrm{Zn}^{2+}$ following GpVI and TP $\alpha$ signalling, but not via PARs. Unlike conventional agonists, Cq stimulation resulted in PS exposure in a majority of platelets. This may indicate that agonist-evoked $\mathrm{Zn}^{2+}$ signals are stimulated in only a sub-set of platelets, which then proceed to become procoagulant. As previously shown (-Fig. 3), Cq stimulation did not induce increases in $\left[\mathrm{Ca}^{2+}\right]_{\text {, }}$, so Cq-dependent PS exposure is independent of $\left[\mathrm{Ca}^{2+}\right]_{i}$. Platelet PS exposure has been attributed to both caspase 3-dependent and independent mechanisms. ${ }^{51,52}$ Cq-dependent PS exposure is partially abrogated by Z-VAD pre-treatment suggesting a partial role for caspase activity in this process.

In conclusion, this study provides the first evidence for agonist-evoked increases of $\left[\mathrm{Zn}^{2+}\right]_{i}$ in platelets. While requiring further confirmation, such behaviour is consistent with a role of $\mathrm{Zn}^{2+}$ as a secondary messenger. Increases in $\left[\mathrm{Zn}^{2+}\right]_{\mathrm{i}}$ are sensitive to the redox state, indicative of a role for redox in agonist-evoked $\mathrm{Zn}^{2+}$ signalling. Modelling increases of $\left[\mathrm{Zn}^{2+}\right]_{\mathrm{i}}$ using $\mathrm{Zn}^{2+}$-specific ionophores reveal a functional role for $\left[\mathrm{Zn}^{2+}\right]_{\mathrm{i}}$ in platelet activatory changes. $\left[\mathrm{Zn}^{2+}\right]_{\mathrm{i}}$ signalling contributes to key activation-related platelet responses, including shape change, $\alpha_{\mathrm{IIb}} \beta_{3}$ activation and granule release. The mechanism by which $\mathrm{Zn}^{2+}$ affects these processes is currently unknown, but could be attributable to changes in activity of $\mathrm{Zn}^{2+}$-binding enzymes. These data indicate a hitherto unknown role for labile $\left[\mathrm{Zn}^{2+}\right]_{i}$ during platelet activation, which has implications for our understanding of signalling responses in platelets. While this work does not address the physiological relevance of this process, a better understanding of $\mathrm{Zn}^{2+}$ signalling may be of significance to the role of platelets in thrombotic disorders such as heart attack and stroke. 
Furthermore, as they are readily available primary cells, platelets could be used as a model to better understand $\mathrm{Zn}^{2+}$ signalling in other mammalian cells.

\section{What is known about this topic?}

- Zinc is an intracellular secondary messenger in nucleated cells.

- Agonist-dependent fluctuations of zinc in platelets, leading to functional changes, have yet to be demonstrated.

\section{What does this paper add?}

- Intra-platelet zinc increases in concentration following agonist stimulation.

- Increases in zinc regulate activatory processes, including aggregation, shape change and PS exposure.

- This is the first work to demonstrate a role for zinc in agonist-dependent signal transduction in platelets.

\section{Authors' Contributions}

N.S.A., M.L.P. and N.P. designed and conducted experiments, and wrote the manuscript. N.S.A., M.L.P., K.T. and N.P. designed experiments and wrote the manuscript.

\section{Funding}

This work was supported by British Heart Foundation project grants (PG/14/47/30912 and PG/18/64/33922).

\section{Conflict of Interest}

None declared.

\section{References}

1 Andreini C, Bertini I. A bioinformatics view of zinc enzymes. J Inorg Biochem 2012;111:150-156

2 Blakemore LJ, Trombley PQ. Zinc as a neuromodulator in the central nervous system with a focus on the olfactory bulb. Front Cell Neurosci 2017;11:297

3 Maret W. Zinc in cellular regulation: the nature and significance of "zinc signals". Int J Mol Sci 2017;18(11):E2285

4 Taylor KA, Pugh N. The contribution of zinc to platelet behaviour during haemostasis and thrombosis. Metallomics 2016;8(02): 144-155

5 Sharir H, Zinger A, Nevo A, Sekler I, Hershfinkel M. Zinc released from injured cells is acting via the $\mathrm{Zn}^{2+}$-sensing receptor, $\mathrm{ZnR}$, to trigger signaling leading to epithelial repair. J Biol Chem 2010; 285(34):26097-26106

6 Bernardo MM, Day DE, Olson ST, Shore JD. Surface-independent acceleration of factor XII activation by zinc ions. I. Kinetic characterization of the metal ion rate enhancement.J Biol Chem 1993; 268(17):12468-12476

7 Watson BR, White NA, Taylor KA, et al. Zinc is a transmembrane agonist that induces platelet activation in a tyrosine phosphorylation-dependent manner. Metallomics 2016;8(01):91-100

8 Yamasaki S, Sakata-Sogawa K, Hasegawa A, et al. Zinc is a novel intracellular second messenger.J Cell Biol 2007;177(04):637-645

9 Haase H, Ober-Blöbaum JL, Engelhardt G, et al. Zinc signals are essential for lipopolysaccharide-induced signal transduction in monocytes. J Immunol 2008;181(09):6491-6502
10 Haase H, Maret W. Fluctuations of cellular, available zinc modulate insulin signaling via inhibition of protein tyrosine phosphatases. J Trace Elem Med Biol 2005;19(01):37-42

11 Arslan P, Di Virgilio F, Beltrame M, Tsien RY, Pozzan T. Cytosolic $\mathrm{Ca} 2+$ homeostasis in Ehrlich and Yoshida carcinomas. A new, membrane-permeant chelator of heavy metals reveals that these ascites tumor cell lines have normal cytosolic free $\mathrm{Ca} 2+$. J Biol Chem 1985;260(05):2719-2727

12 Hyun TH, Barrett-Connor E, Milne DB. Zinc intakes and plasma concentrations in men with osteoporosis: the Rancho Bernardo Study. Am J Clin Nutr 2004;80(03):715-721

13 Matias CM, Sousa JM, Quinta-Ferreira ME, Arif M, Burrows HD. Validation of TPEN as a zinc chelator in fluorescence probing of calcium in cells with the indicator Fura-2.J Fluoresc 2010;20(01): 377-380

14 Qian C, Colvin RA. Zinc flexes its muscle: correcting a novel analysis of calcium for zinc interference uncovers a method to measure zinc. J Gen Physiol 2016;147(01):95-102

15 Zhao J, Bertoglio BA, Gee KR, Kay AR. The zinc indicator FluoZin-3 is not perturbed significantly by physiological levels of calcium or magnesium. Cell Calcium 2008;44(04):422-426

16 Maret W. Metallothionein/disulfide interactions, oxidative stress, and the mobilization of cellular zinc. Neurochem Int 1995;27(01): $111-117$

17 Beckman JS, Minor RL Jr, White CW, Repine JE, Rosen GM, Freeman BA. Superoxide dismutase and catalase conjugated to polyethylene glycol increases endothelial enzyme activity and oxidant resistance. J Biol Chem 1988;263(14):6884-6892

18 Bakdash N, Williams MS. Spatially distinct production of reactive oxygen species regulates platelet activation. Free Radic Biol Med 2008;45(02):158-166

19 Rosado JA, Redondo PC, Salido GM, Gómez-Arteta E, Sage SO, Pariente JA. Hydrogen peroxide generation induces pp60src activation in human platelets: evidence for the involvement of this pathway in store-mediated calcium entry. J Biol Chem 2004; 279(03):1665-1675

20 Marx G, Korner G, Mou X, Gorodetsky R. Packaging zinc, fibrinogen, and factor XIII in platelet alpha-granules. J Cell Physiol 1993; 156(03):437-442

21 White JG, Rao GH, Gerrard JM. Effects of the lonophore A23187 on blood platelets I. Influence on aggregation and secretion. Am J Pathol 1974;77(02):135-149

22 Fujikawa K, Fukumori R, Nakamura S, Kutsukake T, Takarada T, Yoneda Y. Potential interactions of calcium-sensitive reagents with zinc ion in different cultured cells. PLoS One 2015;10(05):e0127421

23 Aiba I, West AK, Sheline CT, Shuttleworth CW. Intracellular dialysis disrupts $\mathrm{Zn} 2+$ dynamics and enables selective detection of Zn2+ influx in brain slice preparations. J Neurochem 2013;125 (06):822-831

24 Park M-H, Lee S-J, Byun HR, et al. Clioquinol induces autophagy in cultured astrocytes and neurons by acting as a zinc ionophore. Neurobiol Dis 2011;42(03):242-251

25 Pula G, Schuh K, Nakayama K, Nakayama KI, Walter U, Poole AW. PKCdelta regulates collagen-induced platelet aggregation through inhibition of VASP-mediated filopodia formation. Blood 2006; 108(13):4035-4044

26 Getz TM, Dangelmaier CA, Jin J, Daniel JL, Kunapuli SP. Differential phosphorylation of myosin light chain (Thr)18 and (Ser)19 and functional implications in platelets. J Thromb Haemost 2010;8 (10):2283-2293

27 Smolenski A. Novel roles of cAMP/cGMP-dependent signaling in platelets. J Thromb Haemost 2012;10(02):167-176

28 Iitaka M, Kakinuma S, Fujimaki S, et al. Induction of apoptosis and necrosis by zinc in human thyroid cancer cell lines. J Endocrinol 2001;169(02):417-424

29 Eron SJ, MacPherson DJ, Dagbay KB, Hardy JA. Multiple mechanisms of zinc-mediated inhibition for the apoptotic caspases $-3,-6$, -7, \& -8. ACS Chem Biol 2018;13(05):1279-1290 
30 Treves S, Trentini PL, Ascanelli M, Bucci G, Di Virgilio F. Apoptosis is dependent on intracellular zinc and independent of intracellular calcium in lymphocytes. Exp Cell Res 1994;211(02):339-343

31 Hamatake M, Iguchi K, Hirano K, Ishida R. Zinc induces mixed types of cell death, necrosis, and apoptosis, in molt-4 cells. J Biochem 2000;128(06):933-939

32 Cohen Z, Wilson J, Ritter L, McDonagh P. Caspase inhibition decreases both platelet phosphatidylserine exposure and aggregation: caspase inhibition of platelets. Thromb Res 2004;113(06): 387-393

33 Sugiura T, Nakamura H. Metallothionein in platelets. Int Arch Allergy Immunol 1994;103(04):341-348

34 Meeusen JW, Nowakowski A, Petering DH. Reaction of metalbinding ligands with the zinc proteome: zinc sensors and $\mathrm{N}, \mathrm{N}, \mathrm{N}^{\prime}$, N'-tetrakis(2-pyridylmethyl)ethylenediamine. Inorg Chem 2012 . 51(06):3625-3632

35 Li F, Abuarab N, Sivaprasadarao A. Reciprocal regulation of actin cytoskeleton remodelling and cell migration by $\mathrm{Ca} 2+$ and $\mathrm{Zn} 2+$ : role of TRPM2 channels. J Cell Sci 2016;129(10):2016-2029

36 Krezel A, Hao Q, Maret W. The zinc/thiolate redox biochemistry of metallothionein and the control of zinc ion fluctuations in cell signaling. Arch Biochem Biophys 2007;463(02):188-200

37 Krężel A, Maret W. The functions of metamorphic metallothioneins in zinc and copper metabolism. Int J Mol Sci 2017;18(06): E1237

38 Begonja AJ, Gambaryan S, Geiger J, et al. Platelet NAD(P)Hoxidase-generated ROS production regulates alphallbbeta3integrin activation independent of the NO/cGMP pathway. Blood 2005;106(08):2757-2760

39 Rudolf E, Klvacová L, John S, Cervinka M. Zinc alters cytoskeletal integrity and migration in colon cancer cells. Acta Med (Hradec Kralove) 2008;51(01):51-57

40 Perrin L, Roudeau S, Carmona A, et al. Zinc and copper effects on stability of tubulin and actin networks in dendrites and spines of hippocampal neurons. ACS Chem Neurosci 2017;8(07): 1490-1499

41 Mackenzie GG, Oteiza PI. Zinc and the cytoskeleton in the neuronal modulation of transcription factor NFAT. J Cell Physiol 2007;210(01):246-256

42 Hathaway DR, Adelstein RS. Human platelet myosin light chain kinase requires the calcium-binding protein calmodulin for activity. Proc Natl Acad Sci U S A 1979;76(04):1653-1657

43 Mills JS, Johnson JD. Metal ions as allosteric regulators of calmodulin. J Biol Chem 1985;260(28):15100-15105

44 Heijnen $H$, van der Sluijs P. Platelet secretory behaviour: as diverse as the granules ... or not? J Thromb Haemost 2015;13(12): 2141-2151

45 Golebiewska EM, Poole AW. Platelet secretion: from haemostasis to wound healing and beyond. Blood Rev 2015;29(03):153-162

46 Mann JJ, Fraker PJ. Zinc pyrithione induces apoptosis and increases expression of Bim. Apoptosis 2005;10(02):369-379

47 Rudolf E, Červinka M. Zinc pyrithione induces cellular stress signaling and apoptosis in Hep-2 cervical tumor cells: the role of mitochondria and lysosomes. Biometals 2010;23(02):339-354

48 Truong-Tran AQ, Ho LH, Chai F, Zalewski PD. Cellular zinc fluxes and the regulation of apoptosis/gene-directed cell death. J Nutr 2000;130(5S, Suppl):1459S-1466S

49 Kondoh M, Tasaki E, Takiguchi M, Higashimoto M, Watanabe Y, Sato M. Activation of caspase-3 in HL-60 cells treated with pyrithione and zinc. Biol Pharm Bull 2005;28(04):757-759

50 Zhu B, Wang J, Zhou F, et al. Zinc depletion by TPEN induces apoptosis in human acute promyelocytic NB4 cells. Cell Physiol Biochem 2017;42(05):1822-1836

51 Gyulkhandanyan AV, Mutlu A, Freedman J, Leytin V. Markers of platelet apoptosis: methodology and applications. J Thromb Thrombolysis 2012;33(04):397-411

52 Leytin V. Apoptosis in the anucleate platelet. Blood Rev 2012;26 (02):51-63 